Research Paper

\title{
Law and Social Dynamics of Society
}

\section{Andrew Shandy Utama ${ }^{1}$}

${ }^{1}$ Faculty of Law, Universitas Muhammadiyah Riau. Riau, Indonesia.

Article History

Received:

16.08.2021

Revised:

16.09.2021

Accepted:

22.09.2021

*Corresponding Author:

Andrew Shandy Utama

Email:

andrewshandyutama@umri.ac.id

This is an open access article, licensed under: $C C-B Y-S A$

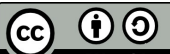

Abstract: This research aims to explain the influence of law on the social dynamics of society. The method used in this research is normative legal research. One of the sciences that studies the social dynamics of society is the Sociology of Law. Every dynamic that occurs as a result of social change requires a legal response. Social dynamics is a general phenomenon that occurs throughout the ages in every society, changes that occur in accordance with the nature and nature of humans who always want to make changes. The occurrence of social dynamics is influenced by several factors, including law, technology, community structure, culture, an open system of social stratification, and advanced education. Community institutions are considered truly valid if their norms fully assist the implementation of social patterns. The system of social layers can occur by itself or is deliberately structured to pursue a common goal. Legal coercion in the implementation of social institutions that apply as regulations is not always used. Instead, the emphasis is on the coercion of society.

Keywords: Law, Social Dynamics, Society. 


\section{Introduction}

The process of change in society in today's world is a normal phenomenon whose influence spreads quickly to other parts of the world, partly thanks to the existence of modern communication with a rapidly developing level of technology. New discoveries in the field of technology, a revolution, the modernization of education, and other events that occur in one place can quickly be recognized by other people who live far from the center of the incident. Changes in society can be about values, rules, patterns of behavior, organization, structure of social institutions, social stratification, power, social interaction, and so on.

Due to the wide field in which dynamics in society may occur, these changes as a process will only be discovered by people who have studied the life of a society at a certain time structure and then compare it with the composition and life of the community in the past. . Someone who does not have time to examine the composition and life of rural communities in Indonesia, for example, will argue that these rural communities are not progressing and have not even changed at all. The statement above is usually based on a cursory view that is less thorough and not deep because no society stops at a certain point in its development throughout time. Therefore, it is difficult to say that there are still many rural communities in Indonesia that are still remote.

From the background described above, the problem discussed in this study is how the law influences the social dynamics of society.

\section{Research Methodology}

Legal research is a scientific activity based on methods, systematics, and certain thoughts that aim to study one or more specific legal phenomena by analyzing them [1]. The method used in this research is normative legal research. Normative legal research is a process to find legal rules, legal principles, and legal doctrines in order to answer legal issues faced [2]. Sources of data used in this study are secondary data, namely data obtained from statutory regulations, scientific journals, and legal literature. The data collection technique used in this research is literature study. The data analysis technique used in this research is qualitative analysis.

\section{Discussions}

One of the sciences that studies the social dynamics of society is the Sociology of Law. Sociology of Law comes from two words, namely Sociology and Law. In the Big Indonesian Dictionary, it is explained that the definition of Sociology is knowledge or science about the nature, behavior, and development of society. In addition, Sociology is also defined as the science of social structure, social processes, and changes. Meanwhile, in the Big Indonesian Dictionary it is explained that the definition of law is a regulation or custom that is officially considered binding, which is confirmed by the ruler or government. Law is also defined as laws, regulations, and so on to regulate the social life of the community. In addition, the law is defined as a benchmark (rules, provisions) regarding certain events (nature and so on). Finally, the definition of law in the Big Indonesian Dictionary is a decision (consideration) determined by a judge (in court), or a verdict [3].

The term Sociology of Law was first used in 1882 by a philosopher named Anziolotti. Anziolotti views law as a social reality, not as a rule. Anziolotti also views law as a social phenomenon that is different from normative law as positive norms in national laws and regulations. Several experts who influenced the development of Sociology of Law as a science were Emile Durkheim, Max Weber, Eugen Ehrlich, Talcott Parsons, and Roscoe Pound. [4].

The term Sociology of Law in English comes from the term Sociology of Law which means it is one of the studies in sociology that studies social science disciplines.

According to Anthony Giddens, Sociology of Law is the study of human social life, human groups, and society. According to Auguste Comte, Sociology of Law is a positive study of the basic laws of various social phenomena, which are divided into static sociology and dynamic sociology. Meanwhile, Brade Meyer argues that Sociology of Law is a science that focuses on law as social research so that in this effort the public's view of the regulations that occur and their impacts will be seen. In addition, the Sociology of Law focuses more on social phenomena as an act of seeing legal certainty [5].

Emile Durkheim argues that the Sociology of Law is the study of social facts. Social facts are ways of acting, thinking, and being able to exert external coercion on individuals. 
In line with that, J. A. A. von Doorn and C. J. Lammers argued that the Sociology of Law is the science of stable social structures and processes. According to Max Weber, Sociology of Law is a science that seeks to understand social actions, namely actions that are carried out by considering and oriented to the behavior of others [6].

According to Major Polak, Sociology of Law is a science that studies society as a whole, namely the relationship between humans and other humans, the relationship between humans and groups, the relationship between groups and groups, both formal groups and informal groups or both static groups and dynamic groups. Meanwhile, Paul B. Horton explained that Sociology of Law is a science that focuses on the study of group life and the products of that group's life [7].

Pitirim A. Sorokin argues that Sociology of Law is a science that studies about:

1. The reciprocal relationship and influence between various kinds of social phenomena, for example between legal and religious phenomena, legal and moral phenomena, legal and economic phenomena, and so on.

2. Relation and reciprocal influence between social phenomena and non-social phenomena.

3. General characteristics of all kinds of social phenomena.

Roucek and Warren argue that the Sociology of Law is a science that studies human relations in groups. According to William F. Ogburn and Mayer F. Nimkoff, Sociology of Law is a scientific study of social interaction and its results, namely social organization.

In Indonesia, Hassan Shandily explained that Sociology of Law is a science that studies living together in society and investigates the bonds between humans that rule life by trying to understand the nature and purpose of living together, how to form and grow, and the changing associations of life and trust. According to Mochtar Kusumaatmadja, Sociology of Law is a science that focuses on rules and principles in human life, until finally the discipline of Sociology of Law will bring peace and order together between communities [8].

Finally, Soetandyo Wignjosoebroto explained that Sociology of Law is a branch of sociology that focuses on legal issues as an effort to create peace and togetherness in society. Sociology of Law focuses its attention on legal matters so that they can be realized as part of the experiences of everyday people's lives. In addition, Sociology of Law studies human life in society in general, which is devoted to human efforts to enforce the law and prosper life and has a different specialty from you in other branches of sociology.

Social life in society is a complex system that regulates all aspects of life in society. This is a legacy passed down from generation to generation by the previous ancestors. The complex life system starts from the existence of social interaction into a social process, which in turn forms social groups. These social groups will produce culture in society. After that, community groups began to unite to form community institutions. Increasingly complex social life will form social stratification in society, which will lead to social dynamics in people's lives. The social life of the community begins with a social process. Social processes are related ways that can be seen when individuals and groups meet each other and determine the system. The general form of social processes is social interaction because social interaction is the main condition for the occurrence of social activities. Social interaction is the key to all social life, because without social interaction, there will be no life together.

Social interaction between human groups also occurs in society. This interaction is more striking when there is a conflict between individual interests and group interests. An example is in the case of a teacher dealing with his students who are a group of people in the classroom. The ongoing process of interaction is based on various factors, including the imitation factor, the suggestion factor, the identification factor, and the sympathy factor. The positive side of the imitation factor is that the imitation factor can encourage a person to comply with the rules of applicable values. The suggestion factor takes place when someone gives a view or an attitude that comes from himself, which is then accepted by the other party. Identification is actually the tendencies or desires in a person to be the same as others. Identification is deeper than imitation because a person's personality can be formed on the basis of this process. The sympathy factor is actually a process in which a person feels attracted to another party. In this process, feelings play a very important role, although the main impetus for sympathy is the desire to understand the other party and to cooperate with him.

A social interaction will not be possible if there is no social contact and no communication. Social contact can take place in three forms, namely social contact between individuals, social contact between individuals and a human group or vice versa, and social contact between a human group and 
other human groups. The importance of communication is that a person gives an interpretation to the behavior of another person regarding the feelings that the person wants to convey. With the existence of communication, it will further open the relationship between community groups.

The importance of contact and communication for the realization of social interaction can be tested in an isolated life. Forms of social interaction can be in the form of cooperation, competition, and can even take the form of a conflict or dispute which will eventually find a solution. The social interaction that occurs will be the beginning of the formation of social groups in society. Humans are generally born alone, but humans are social creatures who have the instinct to live with other people. Almost all humans are originally members of a social group, which is called a family. Although the family members are always scattered, but at certain times they will definitely gather, for example at night, all family members will gather in the house. A social group is a set or unity of people who live together because of the relationship between them. These relationships, among others, involve reciprocal relationships that influence each other and also an awareness to help each other.

Social groups that have been formed in society will begin to look for forms and directions of life together, which will indirectly produce what is called community culture. According to anthropologist E. B. Taylor, culture is a complex that includes knowledge, belief, art, morals, law, customs, and other capabilities and habits acquired by humans as members of society. Culture is produced and owned by the community [10].

The elements of culture that are considered as cultural universals are tools and equipment for human life, livelihoods and economic systems, social systems, language, arts, knowledge systems, and the last is a belief system. Some of the cultural elements above were written by C. Kluckhohn in his work entitled 'Universal Categories of Culture'. In social life, gradually over time, community groups that are getting more advanced and more and more in number will begin to think of something that can unite the needs between them. This is the forerunner of the community to form social institutions or social institutions in society. The need for kinship gives rise to social institutions such as marriage. The need for a livelihood has given rise to social institutions such as cooperatives, and many other social institutions.

The process of the growth of social institutions begins with the norms in society. In order for human relations in a society to be carried out as expected, community norms are formulated. At first these norms were formed by accident. However, over time these norms are made consciously. The norms that exist in society have different binding powers. There are norms that are weak, moderate, to the strongest. In this last norm, generally members of the public do not dare to violate it. To be able to distinguish the binding power of these norms, sociologically there are four understandings, namely ways, habits, behavior, and customs. Each of the above understandings has the same basis, namely social norms that provide instructions for the behavior of someone who lives in society. The explanation is as follows:

1. How to be more prominent in the relationships between individuals in society. A deviation from it will not result in severe punishment, only reproach.

2. Habits have a greater binding power than methods. Habits that are interpreted as actions that are repeated in the same form are evidence that many people like these actions.

3. The code of conduct reflects the living characteristics of human groups, which are carried out as a monitoring tool, consciously or unconsciously, by the community towards members of the community. Code of conduct is very important because it provides limits on individual behavior, identifies individuals with their groups, and maintains solidarity between community members.

4. Eternal code of conduct and its strong integration with community behavior patterns can increase the strength of binding it into a custom. Usually people who violate it will be expelled from society.

Community institutions are considered truly valid if their norms fully assist the implementation of social patterns. Legal coercion in the implementation of social institutions that apply as regulations is not always used. Instead, the emphasis is on the coercion of society. In social institutions, what really applies is the coercive factor depending on considerations of welfare, mutual cooperation, cooperation, and so on. No matter how hard the efforts of a party to try to make a norm accepted by society, the norm will not be institutionalized in society. A certain norm is said to have been institutionalized if the norm is known, understood, obeyed, and appreciated by the community. 
The next process is the social control system. In everyday conversation, the social control system is often interpreted as supervision by the community over the running of the government, especially the government and its apparatus. Social control aims to achieve harmony between stability and dynamics in society. Coercion is more often needed in a changing society, because in such circumstances social control serves to form new rules that replace old ones that have faltered.

Roscoe Pound theorizes that Law as a Tool of Social Engineering, which means that law is a tool for engineering social life in society [11]. The social life of a society that is increasingly diverse and continues to grow will always seek new forms that can make the bonds between them stronger. After the formation of social institutions in the midst of society, new paradigms will emerge among them. There will be views and differences of thought caused by interaction and technological advances. Gradually, community groups that are in line with their thoughts will form a certain group and determine the leaders who are seen and respected among them.

Every society always has a certain appreciation for certain things in the society concerned. Higher respect for certain things will place them in a higher position than other things. If a society values material wealth more than honor, then those with more wealth will occupy a higher position in society. Symptoms that trigger the emergence of social layers in society. Symptoms like this are natural to occur over time in accordance with the times. The forms of layers of society are different and numerous. These layers still exist even in capitalist, democratic, communist societies, and so on. Layers of society began to exist since humans recognize the existence of life together in a social organization. In small and modest societies, usually the distinction between positions and roles is minimal, because the population is small and there are not many people who are considered high in position.

However, in an already complex society, the distinction between positions and roles is also complex, due to the large number of people and the various colors and sizes that can be applied to them. The system of social layers can occur by itself or is deliberately structured to pursue a common goal. As long as in one society there is something that is valued, and every society must have something to value, that something will become a seed that can grow a system of layers in society. Social groups in society are not static groups. Every society must experience development, which leads to change. Changes in society can be about its social values, social norms, patterns of organizational behavior, the composition of social institutions, social stratification in society, and so on.

With the recognition of dynamics as the core of the soul of society, it will become an interesting discourse to continue to study about the dynamics that occur in a society. Social dynamics in society can occur due to many factors. There are factors that come from within the community itself (internal factors) and there are factors that come from outside the community (external factors), one of which is influenced by the state system that is enforced. One of the state systems imposed by the authorities is enforcing the legal system adopted in a country. In Indonesia, by adopting and enforcing a system of legal positivism, which separates law and morals, of course, it will bring its own influence on social life that has been built and lives naturally in society [12].

The social life of the community, ranging from social interaction between communities, the existence of social groups in society, the birth of various cultures, the formation of social institutions, the existence of stratification in society, to its development is a picture of the complex social life of society. However, the natural life of the community is challenged by the legal system imposed by the state [13].

In West Sumatra, the existence of Nagari as a traditional village is the fruit of the long struggle of the Minangkabau people and the local government. The enactment of Law Number 6 of 2014 concerning Villages has further strengthened the legal basis for Nagari to maintain their existence as Minangkabau cultural heritage in West Sumatra [14]. Meanwhile in Riau, Riau Province Regional Regulation Number 6 of 2012 stipulates that every company in Riau Province is obliged to implement Corporate Social Responsibility programs. Article 11 of the Regional Regulation of Riau Province Number 6 of 2012 stipulates that one of the areas of work for Corporate Social Responsibility can be carried out in the field of people's economic business. Corporate Social Responsibility programs from large companies, both national and international levels operating in Riau Province are useful for building the economy of rural communities [15].

The legal positivism system adopted by the Indonesian state is slowly causing a shift in social values that exist in society. So, by adopting a legal positivism system as a state legal system, it will 
trigger a shift in moral values in society and cause social change in society. The community is indirectly forced to start abandoning traditional values and habits that have been preserved so far. People are forced to submit to written legal rules issued by the state, accompanied by strict sanctions for those who violate them.

No matter how hard the efforts of a party to try to make a norm accepted by society, the norm will not be institutionalized in society. A certain norm is said to have been institutionalized if the norm is known, understood, obeyed, and appreciated by the community.

\section{Conclusions}

One of the sciences that studies the social dynamics of society is the Sociology of Law. Every dynamic that occurs as a result of social change requires a legal response. Social dynamics is a general phenomenon that occurs throughout the ages in every society, changes that occur in accordance with the nature and nature of humans who always want to make changes. The occurrence of social dynamics is influenced by several factors, including law, technology, community structure, culture, an open system of social stratification, and advanced education. Community institutions are considered truly valid if their norms fully assist the implementation of social patterns. The system of social layers can occur by itself or is deliberately structured to pursue a common goal. Legal coercion in the implementation of social institutions that apply as regulations is not always used. Instead, the emphasis is on the coercion of society. In social institutions, what really applies is the coercive factor depending on considerations of welfare, mutual cooperation, cooperation, and so on. Social dynamics in society can occur due to many factors. There are factors that come from within the community itself (internal factors) and there are factors that come from outside the community (external factors), one of which is influenced by the state system that is enforced.

\section{References}

[1] S. Seokanto, Introduction to Legal Research. Jakarta: UI Press, 2007.

[2] P. M. Marzuki, Legal Research. Jakarta: Kencana, 2011.

[3] Z. Ali, Sociology of Law. Jakarta: Sinar Grafika, 2012.

[4] S. Soekanto, Sociology; An Introduction. Jakarta: Rajawali Pers, 2006.

[5] B. L. Tanya, Y. N. Simanjuntak, and M. Y. Hage, Legal Theory. Yogyakarta: Genta Publishing, 2010.

[6] A. Suadi, Sociology of Law. Jakarta: Kencana Prenada Media, 2018.

[7] A. Ali and W. Heryani, Sociology of Law. Jakarta: Kencana Prenada Media, 2015.

[8] A. Ali, Legal Theory and Justice Theory. Jakarta: Kencana Prenada Media, 2009.

[9] R. O. Salman and A. F. Susanto, Legal Theory. Bandung: Refika Aditama, 2010.

[10] N. Ngani, The Development of Indonesian Customary Law. Yogyakarta: Pustaka Yustisia, 2012.

[11] T. Prasetyo, and A. H. Barkatullah, Philosophy, Theory, and Law. Jakarta: Rajawali Pers, 2012.

[12] A. S. Utama. "Public Trust in Law Enforcement in Indonesia," Ensiklopedia Social Review Journal, vol. 1, no. 3, 2019.

[13] Suteki, Law and Society. Yogyakarta: Thafa Media, 2021.

[14] A. S. Utama, "The Existence of Nagari in West Sumatra as Traditional Villages in the State Administration System in Indonesia Based on Law Number 6 of 2014 concerning Villages," Equitable Journal, vol. 2, no. 1, 2017.

[15] Fahrial., A. S. Utama, and S. Dewi, "Utilization of Corporate Social Responsibility (CSR) on Village Economic Development," Wawasan Yuridika Journal, vol. 3, no. 2, 2019. 